\title{
Pengaruh Capital Intensity dan Inventory Intensity Terhadap Penghindaran Pajak
} (Studi Kasus pada Perusahaan Sub-Sektor Kimia yang Terdapat di BEI Periode 20172019)

\author{
Roslan Sinaga ${ }^{1}$, Harman Malau' ${ }^{2}$ \\ 1,2 Universitas Advent Indonesia \\ Email: roslansinagarang@gmail.com ${ }^{1}$
}

\section{ARTICLE INFO}

Article History:

Received: May 11th 2021

Accepted: May 31 2021

Published: June $9^{\text {th }} 2021$

Keywords:

Capital Intensity, Inventory

Intensity,Tax Avoidance

\begin{abstract}
The purpose of this study was to determine the effect of the results of capital intensity and inventory intensity on tax avoidance in chemical sub-sector companies listed on the Indonesia Stock Exchange. The sample in this study used a purposive method with a total sample of 33 samples from 11 chemical sub-sector companies listed on the Indonesia Stock Exchange from 2017-2019 with company codes as follows AGII, BRPT, BUDI, DPNS, EKAD, INCI, MDKI, MOLI, SRSN, TPIA, UNIC. In this study, capital intensity and inventory intensity as independent variables, and tax avoidance as the dependent variable. And the results of this study indicate that capital intensity has a positive effect on tax avoidance, inventory intensity also has a positive effect on tax avoidance and simultaneously capital intensity and inventory intensity both have a significant effect on tax avoidance.
\end{abstract}

\section{Pendahuluan}

Pembangunan nasional adalah kegiatan yang berkesinambungan dan berkelanjutan yang tujuannya untuk mengembangkan kesejahteraan masyarakat baik dalam bentuk materiil maupun spiritual. Oleh sebab itu perlu adanya perhatian khusus yang harus diberikan pada pendanaan pembangunan negara. Salah satu cara untuk mewujudkan kemandirian negara dalam pendanaan pembangunan adalah dengan mengembangkan sumber daya dalam negeri dalam bentuk pajak. Pajak yang di terima dari wajib pajak yang akan dipakai untuk menghimpun dana pembangunan yang berguna untuk kebaikan bersama Waluyo (2017).

Pajak sebagaimana halnya adalah suatu peraturan yang dibuat oleh pemerintah, sebagai suatu keharusan untuk mengembalikan separuh/sebagian kekayaan pada kas negara yang diakibatkan oleh status, peristiwa dan tindakan tertentu, tetapi bukan sebagai hukuman, dapat ditegakkan, dan pajaknya termasuk dalam nonmigas Mardiasmo (2016). Upaya peningkatan penerimaan negara dari departemen perpajakan perlu terus diupayakan agar pembangunan nasional tetap dapat dilaksanakan atas dasar asas kemandirian sesuai dengan kesanggupannya sendiri. Oleh sebab itu, diperlukan adanya dorongan untuk meningkatkan 
kesadaran masyarakat dalam aspek perpajakan dengan meningkatkan keikutsertaan masyarakat dalam penegakan peraturan perundang-undangan Waluyo (2017). Pajak yang bersifat memaksa dan pembayaran secara berulang-ulang atau sekaligus berdasarkan undang-undang atau hukum, dan tidak adanya imbalan, namun akan menerima manfaat berupa sarana dan prasarana yang di sediakan oleh negara untuk kemakmuran/kesejahteraan masyarakat.

Penghindaran pajak atau yang sering juga disebut penolakan terhadap pajak adalah kendala-kendala yang terjadi dalam pengumpulan pajak sehingga yang terjadi adalah berkurangnya penerimaan kas pada negara. Penghindaran pajak ini merupakan pertentangan aktif yang asalnya dari siwajib pajak. Hal ini dilakukan apabila Surat Ketetapan Pajak belum diterbitkan oleh pemerintah. Wajib pajak yang melakukan penggelapan pajak dapat bervariasi dari wajib pajak ke wajib pajak, dari wajib pajak besar hingga wajib pajak biasa-biasa saja. Pembayar pajak besar cenderung menggunakan kemampuan keuangan mereka yang cukup besar untuk mempekerjakan orang yang dapat diandalkan dan memahami celah dalam undang-undang perpajakan, sementara wajib pajak biasanya mencegah pembelian, penggunaan, atau pekerjaan-pekerjaan tertentu untuk menghindari perpajakan. Berbagai praktik penghindaran pajak yang dilakukan perusahaan untuk menghindari pembayaran pajak tersebut. Salah satunya adalah dengan melakukan pinjaman ke bank dengan nominal yang besar, kemudian pemberian natura dan kenikmatan sehingga hal tersebut menjadi pengurang dari penghasilan bruto perusahaan \{Pasal 6 ayat (1) huruf b)\}.

Untuk menstabilkan atau memaksimalkan perekonomian negara banyak usaha yang dilangsungkan oleh sektor pajak untuk mencapai tujuan tersebut. Namun sektor pajak terkadang memiliki kendala untuk mencapai tujuan tersebut, salah satu yang menjadi kendala adalah adanya penghindaran dari wajib pajak maupun dari perusahaan atau industry. Alasan perusahaan melakukan pengindaran pajak dengan tujuan untuk mengurangi beban perusahaan dan untuk menambah profit bagi perusahaan. Dimana semakin besar Capital atau modal perusahaan maka akan semakin besar pula perusahaan melakukan pembayaran pajak. Begitu juga dengan Inventory atau persediaan, semakin besar persediaan perusahaan, maka akan semakin besar pula pajak yang akan disetor.

Pada saat ini banyak perusahaan yang menjalankan penghindaran pajak, salah satunya dari perusahaan multinasional. Perusahan yang melakukan penghindaran pajak yang cukup tinggi salah satunya adalah perusahaan sub-sektor kimia. Dimana perusahaan ini melakukan penghindaran pajak dari tahun ke tahun sehingga menjadi salah satu penyebab merosotnya penerimaan pajak.

Beberapa faktor yang mempengaruhi penghindaran pajak salah satunya adalah capital intensity dan inventory intensity. Dwiyanti (2019) berpendapat bahwa capital intensity dan inventory intensity berpengaruh positif terhadap pengindaran pajak. Sehingga semakin besar modal yang berupa asset tetap dan persediaan dalam perusahaan, maka akan semakin bertambah juga kemungkinan suatu perusahaan untuk melakukan penghindaran pajak akibat dari penyusutan yang terjadi pada asset tetap untuk setiap tahunnya. Capital Intensity tersebut dapat di ukur dengan total asset tetap bersih dengan total asset, dan 
inventory intensity diukur dengan total persediaan dan total asset. Namun penelitian yang di lakukan oleh Budianti (2018) berbanding terbalik dengan penelitian yang telah dilakukan oleh Dwiyanti (2019).

Penelitian ini bertujuan untuk mengetahui apakah capital intensity berpengaruh signifikan terhadap penghindaran pajak, inventory intensity terhadap penghindaran pajak dan untuk mengetahui apakah capital intensity dan capital intensity sama-sama memiliki pengaruh yang signifikan terhadap penghindaran pajak pada perusahan sub sektor kimia yang terdaftar di Bursa Efek Indonesia (BEI) tahun 2017-2019. Diharapkan bahwa hasil dari penelitian ini akan menjadi bahan kajian yang berguna bagi pihak-pihak yang membutuhkan dan yang tertarik pada kajian ini.

Dari fenomena yang telah diuraikan diatas membuktikan bahwa kurangnya upaya dari beberapa perusahaan dalam melakukan pembayaran pajak diakibatkan besarnya persediaaan atau modal dari beberapa perusahaaan, khususnya pada perusahaan sub-sektor kimia.

\section{Kajian Teori dan Telaah Literatur}

Dalam peraturan Undang-Undang Perpajakan No.28 Tahun 2007, pajak merupakan partisipasi wajib kepada kas negara yang terhutang oleh orang pribadi atau badan yang sifatnya bisa memaksa/dipaksakan berdasarkan Undang-Undang yang berlaku, dengan tidak didapatkan secara langsung dan digunakan sebesar-besarnya keperluan negara dan untuk kemakmuran masyarakat suatu negara. Pajak juga menjadi salah satu sumber pendapatan/penghasilan dalam negeri yang mana pajak yang disetor akan membantu pemerintah dalam program pembangunan negara. Yang menjadi dari pajak salah satunya adalah dalam pembangunan infrastruktur yang bisa dirasakan oleh semua lapisan masyarakt, jadi dengan pajak semua lapisan masyarakat dapat menggunakan fasilitas yang disediakan oleh negara, contohnya jalan raya dan lain-lain. Dengan tidak adanya pungutan pajak maka lapisan masyarakat tidak akan dapat memikmati/ menggunakan setiap fasilitas yang telah disediakan pada saat ini.

\section{Penghindaran Pajak}

Penghindaran pajak atau lebih sering kita sebut dengan tax avoidance merukan suatu kegiatan yang dilakukan untuk mencari keuntungan dengan cara memanfaatkan atau menghindari pajak yang masih dalam kerangka peraturan perpajakan dalam sistem perpajakan negara Indonesia. Dimana juga tax avoidance ini merupakan upaya efesiensi beban pajak dipungut dengan menghindari beban pajak melalui transaksi yang pada dasarnya tidak dikenakan pajak. Penghindaran pajak atau yang sering juga disebut penolakan terhadap pajak adalah kendala-kendala yang terjadi dalam pengumpulan pajak sehingga yang terjadi adalah berkurangnya penerimaan kas pada negara. Penghindaran pajak ini ialah perlawanan aktif yang berasal dari wajib pajak.

Menurut penelitian Sari (2014) Penghindaran pajak adalah salah satu transaksi yang tujuannya untuk memperkecil beban pajak yang akan disetor dengan cara memanfaatkan 
kelemahan dari regulasi perpajakan dalam suatu negara. Menurut Milhanudin (2017) Penghindaran pajak merupakan kegiatan yang bertujuan untuk menghindari yang namanya tanggung jawab atau disebut dengan kewajiban (pembayaran pajak) dan ini bersifat legal karena hal tersebut tidak melanggar ketentuan dari perpajakan.

Penghindaran pajak diukur dengan melihat antara kas yang dikeluarkan perusahaan untuk biaya pajak dan berapa besar laba pada perusahaan sebelum pengurangan beban pajak atau yang biasa disebut dengan Cash Effective Rate (2010). Dan yang digunakan untuk mencari pengdaran pajak adalah sebagai berikut:

$$
\text { CETR }=\frac{\text { Pembayaran Pajak }}{\text { Laba Sebelum Pajak }}
$$

\section{Capital Intensity}

Menurut Nawang (2016) intensitas modal mengacu pada rasio kegiatan pendanaan yang dilakukan oleh suatu perusahaan terkait pendanaan dalam bentuknya aktiva tetap (intensitas modal) dan persediaan (intensitas persediaan). Intensitas modal juga merupakan hasil dari keputusan pendanaan, dan keputusan pendanaan selanjutnya akan menentukan untuk menggunakan liabilities atau hutang untuk mendanai operasi setiap perusahaan. Menurut Mustika (2017) intensitas modal adalah seberapa besar harta tetap yang dimiliki oleh perusahaan tersebut. Dimana harta tetap adalah salah satu aktiva perusahaan yang berdampak mengurangi pendapatan perusahaan. Rasio intensitas modal dapat menunjukkan seberapa efisien perusahaan menggunakan asetnya untuk penjualan. Seorang ahli juga memberikan pendapat pendapat bahwa hampir seluruh asset tetap dapat mengalami depreciation dimana beban penyusutan ini dapat mengurangi pajak perusahaan Pilanoria (2014).

Capital Intensity Ratio merupakan suatu kegiatan pendanaan yang dilakukan oleh perusahaan yang berkesinambungan dengan pendanaan dalam berbentuk aset tetap atau intensitas modal. Rasio intensitas modal mengarah seberapa besar tingkat kemampuan perusahaan dalam menggunakan aktiva tetapnya untuk menghasilkan penjualan/sales. Sebagaimana dijelaskan oleh Hanum (2013), depreciation expense merupakan tarif yang dapat dikurangkan dari pendapatan pada saat menghitung pajak. Oleh karena itu, semakin banyak harta tetap yang perusahaan punya maka semakin besar pula depresiasi sehingga menghasilkan pendapatan kena pajak yang lebih kecil dan tarif pajak efektif. Rumus dari Capital Intensity adalah sebagai berikut:

$$
C A P=\frac{\text { Total Asset tetap bersih }}{\text { Total Aset }}
$$

\section{Inventory Intensity}

Ukuran yang menggambarkan seberapa banyak persediaan yang diinvestasikan dalam suatu perusaaan disebut dengan intensitas persediaan, Rasita (2005). Jika suatu perusahaan memiliki persediaan yang cukup tinggi/besar, maka beban yang akan dikeluarkan oleh 
perusahaan tersebut juga akan tinggi/besar. Semakin besar biaya yang di keluarkan oleh perusahaan untuk meningkatkan investasi persediaan akan dapat menurunkan laba dari perusahaan tersebut.

Untuk intensitas persediaan itu sendiri bisa diukur seberapa besar jumlah persediaan pada akhir periode Perusahaan, dimana beban persediaan tersebut dihitung berdasarkan jumlah Persediaan awal untuk suatu periode ditambah dengan penambahan persediaan, dan totalnya Kurangi dengan persediaan akhir. Sehingga semakin besar total persediaan, maka akan semakin tinggi persediaan perusahaan maka akan semakin tinggi pula biaya persediaan. Dengan tinngginya perhitungan biaya persediaan maka bisa mengurangi laba untuk perusahaan.

Rumus dari Inventory Intensity adalah sebagai berikut:

$$
I N V=\frac{\text { Total Persediaan }}{\text { Total Aset }}
$$

\section{Capital Intensity terhadap Penghindaran Pajak}

Secara garis besar capital Intensity adalah seberapa besar proporsi asset tetap yang dipunyai oleh perusahaan. Rasio intensitas modal dapat menunjukkan seberapa efisien perusahaan menggunakan asetnya untuk penjualan. Perusahaan dengan aset tetap cukup besar akan berpengaruh terhadap pajak yang akan di dibayar, karena semakin besar aset/kekayaan suatu perusahaan maka beban penyusutan untuk aset tetap tersebut akan besar, sehingga beban penyusutan aset tersebut akan mengurangi income atau laba dari perusahaan. Dan jika income/laba perusahaan rendah/menurun maka pajak yang akan di bayarkan/disetorkan otomatis akan berkurang kalimat tersebut diungkapkan oleh Dudy (2015).

Namun berbeda dengan penelitian yang telah dibuat oleh Budianti (2018) yang mana hasil penelitiannya menyatakan bahwa capital intensity tidak berpengaruh terhadapa penghindaran pajak pada suatu perusahaan.

$\mathrm{H}_{1}$ : Capital Intensity Mempunyai Pengaruh yang signifikan terhadap penghindaran pajak.

\section{Inventory Intensity Terhadap Penghindaran Pajak}

Inventory intensity menggambarkan ukuran seberapa banyak inventaris yang diinvestasikan oleh perusahaan. Semakin besar persediaan yang di investasikan suatu perusahaan maka beban perusahaan juga akan tingga, mulai dari biaya pemeliharaan dan biaya penyimpanan persediaan tersebut. Dan semakin tinggi inventory suatu perusahaan maka akan lebih agresif terhadap beban pajak yang akan di terima oleh perusahaan Andary (2017). 
$\mathrm{H}_{2}$ : Inventory Intensity mempunyai pengaruh yang signifikan terhadap penghindaran pajak.

Secara Sistematis, Kerangka berdasarkan teori dan landasan penelitian terdahulu akan di sajikan dalam bentuk gambar 1, yaitu sebagai berikut:

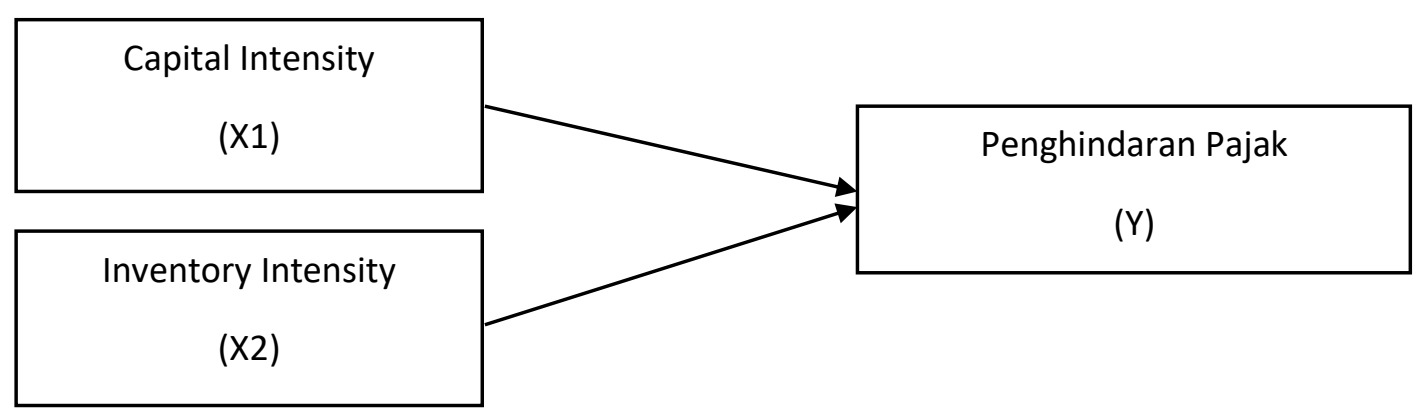

Gambar 1. Kerangka Pemikiran

\section{Metode Penelitian}

\section{Lokasi dan Waktu Penelititan}

Peneliti melakukan penelitian menggunakan data keuangan perusahaan sub-sektor kimia yang terdaftar di Bursa Efek Indonesia tahun 2017-2019 (sebanyak 3 tahun) yang diperoleh dengan menggunakan website BEI.

\section{Populasi dan Sampel}

Populasi yang digunakan pada penelitian ini anatara lain adalah perusahaan sub sektor kimia yang terdapat di Bursa Efek Indonesia (BEI) pada tahun 2017-2019. Sampel yang digunakan pada penelitian ini yaitu teknik purposive sampling, dan di peroleh 11 perusahaan dengan tiga tahun berturut-turut (2017-2019) sehingga total sampel yaitu sebanyak 33 sampel. Adapun kode dari 11 perusahaan tersebut sebagai berikut: AGII, BRPT, BUDI, DPNS, EKAD, INCI, MDKI, MOLI, SRSN, TPIA, UNIC.

\section{Analisis Data}

Analisis data yang dilakukan dalam penelitian ini adalah sebagai berikut: Uji staristik deskriptif, uji normalitas, uji multikolienaritas, uji heteroskedestisitas, uji korelasi, uji determinasi, uji F dan uji T. 


\section{Hasil dan Pembahasan}

\section{Uji Statistik Deskriptif}

Untuk mengetahui uji statistik desktiptif peneliti menggunakan SPSS versi 22. Tabel berikut merupakan ringkasan dari hasil uji deskriptif dengan jumlah sampel 33 dari data perusahaan sub-sektor kimia yang terdaftar di Bursa Efek Indonesia dari tahun 2017- 2019.

Tabel 1. Descriptive Statistics

\begin{tabular}{|c|c|c|c|c|c|}
\hline & $\mathbf{N}$ & Minimum & Maximum & Mean & Std. Deviation \\
\hline $\mathrm{X} 1$ & 33 & .03 & .73 & .4179 & .20368 \\
\hline$X 2$ & 33 & .04 & .45 & .1754 & .12431 \\
\hline $\mathrm{Y}$ & 33 & .00 & 4.00 & .3935 & .79915 \\
\hline Valid N (listwise) & 33 & & & & \\
\hline
\end{tabular}

Dari table di atas dapat di ketahui bahwa nilai minimum Capital Intensity (CAP) adalah 0.03 , nilai maksimum 0.73 , dan rata-ratanya adalah 0.4179 . Nilai minimum pada Inventory Intensity (INV) adalah 0.04, nilai maksimum 0.45 dan rata-ratanya adalah 0.1754 . Dan nilai minimum untuk Penghindaran Pajak (CETR) adalah 0.00, nilai maksimum 4.00, dan rata-rata CETR adalah 0.3935 .

\section{Uji Normalitas}

Hasil uji normalitas dari penelitian ini dapat dilihat pada table berikut:

Tabel 1. Uji Normalitas Kolmogorov-Smirnov

\begin{tabular}{llr}
\hline & & Unstandardized Residual \\
\hline $\mathrm{N}$ & & 33 \\
Normal Parametersa,b & Mean & .0000000 \\
& Std. Deviation & 1.31003916 \\
Most Extreme Differences & Absolute & .129 \\
& Positive & .087 \\
Test Statistic & Negative & -.129 \\
Asymp. Sig. (2-tailed) & & .129 \\
Sumber: Data di olah menggunakan SPSS 22 & $.194^{\mathrm{c}}$ \\
\hline
\end{tabular}

Dari table diatas (hasil uji Kolmogorov-smirnov) menunjukkan bahwa data pada penelitian ini berdistribusi secara normal. Dibuktikan dengan nilai Asymp.sig. (2-tailed) sebesar 0.194 lebih besar dari 0.05 sehingga dapat di simpulkan bahwa data pada penelitian ini normal. 


\section{Uji Multikolienaritas}

Tabel 3. Hasil Uji Multikolinearitas

\begin{tabular}{|c|c|c|c|c|c|c|c|c|}
\hline \multirow{2}{*}{\multicolumn{2}{|c|}{ Model }} & \multicolumn{2}{|c|}{$\begin{array}{l}\text { Unstandardized } \\
\text { Coefficients }\end{array}$} & \multirow{2}{*}{$\begin{array}{c}\begin{array}{c}\text { Standardize } \\
\text { d } \\
\text { Coefficients }\end{array} \\
\text { Beta }\end{array}$} & \multirow[b]{2}{*}{$t$} & \multirow[b]{2}{*}{ Sig. } & \multicolumn{2}{|c|}{$\begin{array}{c}\text { Collinearity } \\
\text { Statistics }\end{array}$} \\
\hline & & B & Std. Error & & & & Tolerance & VIF \\
\hline \multirow[t]{3}{*}{1} & (Constant) & -4.491 & .919 & & -4.889 & .000 & & \\
\hline & Ln_X1 & -.783 & 299 & -.459 & -2.615 & .014 & .860 & 1.163 \\
\hline & Ln_X2 & -.801 & .352 & -.399 & -2.276 & .030 & .860 & 1.163 \\
\hline
\end{tabular}

Sumber: Data di olah menggunakan SPSS 22

Dari table diatas hasil uji multikolienaritas yang memiliki standar VIF lebih kecil dari 10 dan

Tolerance lebih besar dari 0.10 dapat di simpulkan bahwa tidak multikolinearitas di

karenakan nilai dari VIF kurang dari 10 dan Tolerance lebih besar dari 0.10.

Uji Heteroskedestisitas

Tabel 4. Hasil Uji Heteroskedastisitas

\begin{tabular}{|c|c|c|c|c|c|c|c|c|}
\hline \multirow{2}{*}{\multicolumn{2}{|c|}{ Model }} & \multicolumn{2}{|c|}{$\begin{array}{l}\text { Unstandardized } \\
\text { Coefficients }\end{array}$} & \multirow{2}{*}{$\begin{array}{c}\begin{array}{c}\text { Standardized } \\
\text { Coefficients }\end{array} \\
\text { Beta }\end{array}$} & \multirow[b]{2}{*}{$\mathbf{t}$} & \multirow[b]{2}{*}{ Sig. } & \multicolumn{2}{|c|}{$\begin{array}{c}\text { Collinearity } \\
\text { Statistics }\end{array}$} \\
\hline & & B & Std. Error & & & & Tolerance & VIF \\
\hline 1 & (Constant) & .987 & .587 & & 1.683 & .103 & & \\
\hline & Ln_X1 & .058 & .191 & .060 & .303 & .764 & .860 & 1.163 \\
\hline & Ln_X2 & -.034 & .225 & -.030 & -.150 & .882 & .860 & 1.163 \\
\hline
\end{tabular}

Sumber: Data di olah menggunakan SPSS 22

Hasil uji Heteroskedestisitas bahwa Capital Intensity memiliki nilai yang signifikan sebesar

0.764 dan nilai dari Inventory Intensity sebesar 0.882 dimana nilai tersebut lebih besar dari

0.05 sehingga ditarik kesimpulan bahwa penelitian ini tidak terdapat heteroskedestisitas.

\section{Uji Auto Korelasi}

Tabel 5. Hasil Uji Autokorelasi

\begin{tabular}{cccccc}
\hline Model & R & R Square & $\begin{array}{c}\text { Adjusted R } \\
\text { Square }\end{array}$ & $\begin{array}{c}\text { Std. Error of the } \\
\text { Estimate }\end{array}$ & Durbin-Watson \\
\hline 1 & $.379 \mathrm{a}$ & .144 & .087 & .76379 & 1.613 \\
\hline
\end{tabular}

Sumber: Data di olah menggunakan SPSS 22

Berdasarkan hasil uji Auto Korelasi diatas menunjukkan nilai dari D-W sebesar 1.613. Yang mana berdasarkan tabel D-W jika jumlah $\mathrm{n}=33$ dan $\mathrm{K}=3$, maka di ketahui nilai dari $\mathrm{dL}=$ 1.258 dan $\mathrm{dU}=1.651$. Uji autokorelasi memiliki syarat $\mathrm{dU}<\mathrm{D}-\mathrm{W}<4$-dU, berdasarkan data diatas diketahui bahwa $1.651<1.613<2.349$, sehingga bisa disimpulkan bahwa penelitian ini terbebas dari autokorelasi. 


\section{Koefisien Determinasi}

Tabel 6. Hasil Uji Koefisien Determinasi

\begin{tabular}{|c|c|c|c|c|}
\hline Model & $\mathbf{R}$ & R Square & Adjusted R Square & $\begin{array}{l}\text { Std. Error of the } \\
\text { Estimate }\end{array}$ \\
\hline 1 & $.482^{\mathrm{a}}$ & .233 & .180 & 1.35446 \\
\hline
\end{tabular}

Adapun tujuan dari penelitian ini adalah untuk mengetahui pengaruh dari variable dependen (Capital Intensity dan Inventory Intensity) terhadap variable independen (Penghindaran Pajak). Dan hasil dari uji koefisien determinasi yang terdapat pada tabel di atas dimana nilai dari Adjusted R. Square sebesar 0.180 sehingga dapat di tarik kesimpulan bahwa Capital Intensity dan Inventory Intensity memberikan penjelasan pada variable dependen sebesar $18 \%$ dan sisanya adalah sebesar $82 \%$ yang tidak dibahas pada penelitian ini.

\section{Uji-t}

Tabel 7. Hasil Uji-t

\begin{tabular}{|c|c|c|c|c|c|c|}
\hline \multirow{2}{*}{\multicolumn{2}{|c|}{ Model }} & \multicolumn{2}{|c|}{$\begin{array}{c}\text { Unstandardized } \\
\text { Coefficients }\end{array}$} & \multirow{2}{*}{$\begin{array}{c}\text { Standardized } \\
\text { Coefficients } \\
\text { Beta }\end{array}$} & \multirow[b]{2}{*}{$\mathbf{t}$} & \multirow[b]{2}{*}{ Sig. } \\
\hline & & B & Std. Error & & & \\
\hline \multirow[t]{3}{*}{1} & (Constant) & -4.491 & .919 & & -4.889 & .000 \\
\hline & Ln_X1 & -.783 & .299 & -.459 & -2.615 & .014 \\
\hline & Ln_X2 & -.801 & .352 & -.399 & -2.276 & .030 \\
\hline
\end{tabular}

Berdasarkan tabel uji $\mathrm{T}$ diatas di ketahui bahwa nilai signifikan dari Inventory Intensity adalah sebesar 0.014 dimana nilai tersebut lebih kecil dari $0.05(0.014<0.05)$ yang bararti memiliki pengaruh yang signifikan terhadap penghindaran pajak. Kemudian nilai dari Inventory Intensity sebesar 0.03 dimana nilai tersebut lebih kecil dari $0.05(0.03<0.05)$ yang berarti terdapat pengaruh yang signifikan antara Inventory Intensity terhadap Penghindaran Pajak. 


\section{Uji F}

Tabel 8. Hasil Uji F

\begin{tabular}{|c|c|c|c|c|c|c|}
\hline \multirow{4}{*}{$\begin{array}{l}\text { Model } \\
1\end{array}$} & & Sum of Squares & df & Mean Square & $\mathbf{F}$ & Sig. \\
\hline & Regression & 16.139 & 2 & 8.069 & 4.398 & $.021^{\mathrm{b}}$ \\
\hline & Residual & 53.202 & 29 & 1.835 & & \\
\hline & Total & 69.341 & 31 & & & \\
\hline
\end{tabular}

Sumber: Data di olah menggunakan SPSS 22

Dari hasil uji F diatas, di ketahui bahwa jumlah dari F sebesar 4.398 dan nilai signifikan pada tabel adalah sebesar 0.021 yang mana nilai tersebut lebih kecil dari 0.05 sehingga bisa disimpulkan bahwa Capital Intensity dan Inventory Intensity berpengaruh signifikan terhadap Penghindaran Pajak.

\section{Capital Intensity terhadap Penghindaran Pajak}

Dari hasil uji diatas di dapati hasil bahwa Capital Intensity memiliki pengaruh yang signifikan terhadap penghindaran pajak. Dibuktikan dengan nilai dari CAP lebih kecil dari $0.05(0.014<0.05)$ sama halnya dengan hasil penelitian yang dilakukan oleh Muhammad Algifhari (2020) dimana Capital Intensity berpengaruh signifikan terhadap penghindaran pajak. Sehingga dapat di simpulkan bahwa semakin besar modal perusahaan, maka kemungkinan besar pula perusahaan untuk melakukan penghindaran pajak.

\section{Inventory Intensity terhadap Penghindaran Pajak}

Berdasarkan uji $\mathrm{T}$ pada tabel di atas di ketahui bahwa Inventory Intensity memiliki pengaruh yang signifikan terhadap penghindaran pajak. dibuktikan dengan nilai dari inventory intensity sebesar 0.030 dimana nilai tersebut lebih kecil dari $0.05(0.030<0.05)$. Hasil ini sama atau searah dengan penelitian dari Dimas Anindyka S (2015) dimana inventory intensity berpengaruh signifikan terhadap penghindaran pajak. Sehingga bisa di tarik kesimpulan bahwa semakin besar inventory (persediaan) suatu perusahaan, maka semakin besar pula perusahaan melakukan penghindaran pajak.

Dari hasil uji yang telah di lakukan (Uji T) di dapati secara imultan bahwa Capital Intensity dan Inventory Intensity sama-sama berpengaruh signifikan terhadap penghindaran pajak. Hal ini dibuktikan dengan nilai dari signifikasi 0.021 dimana nilai ini lebih kecil dari 0.05 $(0,021<0.05)$. Hasil penelitian ini sejalan dengan penelitian dari Dimas Anindyka S (2015) yang mendapatkan hasil bahwa capital intensity dan inventory intensity sama-sama 
berpengaruh positif. Dan dari hasil penelitian ini kita bisa tarik kesimpulan bahwa semakin besar capital intensity dan inventory intensity maka perusahaan dalam melakukan pembayaran pajak pun akansemakin minim atau rendah.

\section{Penutup dan Saran}

Berdasarkan hasil penelitian yang membahas mengenai pengaruh capital intensity dan inventory intensity terhadap penghindaran pajak pada perusahaan sub-sektor kimia yang terdapat di BEI tahun 2017-2019 maka di tarik kesimpulan sebagai berikut: 1.) terdapat pengaruh yang signifikan antara capital intensity terhadap penghindara pajak pada susektor kimia; 2.) terdapat pengaruh yang signifikan antara inventory intensity terhadap penghindaran pajak pada sub-sektor kimia; 3.) terdapat pengaruh yang signifikan antar capital intensity dan inventory intensity terhadap penghindaran pajak.

Dari simpulan tersebut, disarankan kepada pihak-pihak yang berkepentingan untuk memperhatikan hasil penelitian ini, guna mempertimbangkan dalam melakukan pembayaran pajak kepada negara. Dan untuk peneliti selanjutnya yang ingin mengkaji penelitian ini di harapkan untuk menambahkan beberapa variable dan diharapkan memperluas penggunaan sampel, tidak hanya pada perusahaan Sub-sektor tetapi menambah sektor lainnya yang ada di Bursa Efek Indonesia.

\section{Referensi}

Alghifari, M., Masripah, M., \& Putra, A. M. (2021). Identifikasi Kompensasi Manajemen, Capital Intensity, Leverage terhadap Tax Avoidance. Konferensi Riset Nasional Ekonomi Manajemen dan Akuntansi, 2(1), 1726-1743.

Anggriantari, C. D., \& Purwantini, A. H. (2020, November). Pengaruh Profitabilitas, Capital Intensity, Inventory Intensity, dan Leverage Pada Penghindaran Pajak. In UMMagelang Conference Series (pp. 137-153).

Anindyka, D., Pratomo, D., \& Kurnia, K. (2018). Pengaruh Leverage (Dar), Capital Intensity Dan Inventory Intensity Terhadap Tax Avoidance (Studi Pada Perusahaan Makanan Dan Minuan Di Bursa Efek Indonesia (BEI) Tahun 2011-2015). eProceedings of Management, 5(1), 713-719.

Budianti, S., \& Curry, K. (2018, October). Pengaruh profitabilitas, likuiditas, dan capital intensity terhadap penghindaran pajak (tax avoidance). In Prosiding Seminar Nasional Cendekiawan (pp. 1205-1209).

Damayanti, T., \& Gazali, M. (2018, October). Pengaruh Capital Intensity Ratio Dan Inventory Intensity Ratio Terhadap Effective Tax Rate. In Prosiding Seminar Nasional Cendekiawan (pp. 1237-1242).

Dwiyanti, I. A. I., \& Jati, I. K. (2019). Pengaruh Profitabilitas, Capital Intensity, dan Inventory Intensity pada Penghindaran Pajak. E-Jurnal Akuntansi, 27(3), 2293-2321. 
Furi, G. D., Hardi, \& Rusli. (2018). Pengaruh Leverage, Ukuran Perusahaan, Inventory Intensity, Capital Intensity Ratio, Sales Growth Dan Komisaris Independen Terhadap Tax Avoidance (Studi Empiris Pada Perusahaan Manufaktur yang Terdaftar di Bursa Efek Indonesia Tahun 2014-2016). Jurnal Online Mahasiswa Fakultas Ekonomi, 1(1), 1-15.

Hidayat, A. T., \& Fitria, E. F. (2018). Pengaruh Capital Intensity, Inventory Intensity, Profitabilitas dan Leverage Terhadap Agresivitas Pajak. Eksis: Jurnal Riset Ekonomi dan Bisnis, 13(2), 157-168.

Junaedi, I. K., Sudiartana, I. M., \& Dicriyani, N. L. G. M. (2021). Analisis Pengaruh Profitabilitas, Leverage, Kepemilikan Institusional dan Ukuran Perusahaan Terhadap Tax Avoidanc. KARMA (Karya Riset Mahasiswa Akuntansi), 1(1), 338-345.

Kalbuana, N., Widagdo, R. A., \& Yanti, D. R. (2020). Pengaruh Capital Intensity, Ukuran Perusahaan, dan Leverage Terhadap Tax Avoidance pada Perusahaan yang Terdaftar di Jakarta Islamic Index. Jurnal Riset Akuntansi Politala, 3(2), 46-59.

Lestari, P. A. S., Pratomo, D., \& Asalam, A. G. (2019). Pengaruh Koneksi Politik dan Capital Intensity Terhadap Agresivitas Pajak. Jurnal ASET (Akuntansi Riset), 11(1), 41-54.

Marpaung , N., \& Sudjiman, P. E. (2020). Pengaruh Profitabilitas Dan Leverage Terhadap Penghindaran Pajak Perusahaan Sub-Sektor Kimia Yang Terdaftar Pada Bursa Efek Indonesia Periode 2017-2019. Jurnal Ekonomis, 13(4B), 40-54.

Muzakki, M. R., \& Darsono. (2015). Pengaruh Corporate Social Responsibility Dan Capital Intensity Terhadap Penghindaran Pajak. Diponegoro Journal Of Accounting, 4(3), 1-8.

Rinaldi, M., Respati, N. W., \& Fatimah. (2020). Pengaruh Corporate Social Responsibility, Political Connection, Capital Intensity Dan Inventory Intensity Terhadap Tax Aggressiveness. Jurnal Sitem Informasi, Manajemen dan Akuntansi (SIMAK), 18(2), 149171.

Saputra, W., Suwandi, M., \& Suhartono, S. (2020). Pengaruh Leverage Dan Capital Intensity Terhadap Tax Avoidance Dengan Ukuran Perusahaan Sebagai Variabel Moderasi (Studi Pada Perusahaan Tambang Yang Terdaftar Di Bursa Efek Indonesia Tahun 20172019). ISAFIR Islamic Accounting and Finance Review, 1(1), 29-47.

Savitri , D. A., \& Rahmawati , I. N. (2017). Pengaruh Leverage, Intensitas Persediaan, Intensitas Aset Tetap, Dan Profitabilitas Terhadap Agresivitas Pajak. Jurnal Ilmu Manajemen dan Akuntansi Terapan (JIMAT), 8(2), 19-32.

Sholeha, Y. M. (2019). Pengaruh Capital Intensity, Profitabilitas, Dan Sales Growth Terhadap Tax Avoidance. Jurnal Akuntansi AKUNESA, 7(2).

Sitorus, R. R., \& Wibowo, A. T. (2018). Pengaruh Capital Intensity Dan Inventory Intensity Terhadap Agresivitas Pajak Yang Dimoderasi Oleh Gcg (Good Corporate Governance). Media Akuntansi Perpajakan, 3(2), 17-27. 